\title{
PELAKSANAAN SUPERVISI AKADEMIK YANG BERKELANJUTAN DI SD N 17 DANGIN PURI UNTUK MENINGKATKAN KOMPETENSI GURU DALAM MENYUSUN RENCANA PELAKSANAAN PEMBELAJARAN (RPP)
}

\author{
Drs. Ida Bagus Made Wibawa ${ }^{1}$
}

\begin{abstract}
ABSTRAK
Penelitian Tindakan Sekolah (PTS) ini membahas tentang pelaksanaan supervisi akademik yang berkelanjutan di SD N 17 Dangin Puri dalam upaya meningkatkan kompetensi guru menyusun Rencana Pelaksanaan Pembelajaran. Penelitian ini dilaksanakan pada semester I Tahun Pelajaran 2018/2019. Teknik pengumpulan data yang digunakan meliputi wawancara, observasi dan dokumentasi. Subyek penelitian tindakan sekolah ini adalah semua guru di SD Negeri 17 Dangin Puri yang berjumlah 12 (dua belas) guru. Rancangan penelitian ini adalah model siklus yang dilakukan secara berulang dan berkelanjutan (siklus spiral) melalui dua siklus, setiap siklus meliputi tahap perencanaan, tahap tindakan dan pengamatan, serta tahap refleksi. Hipotesis dianalisis menggunakan metode deskriptif dengan pendekatan analisis kualitatif. Langkah-langkah analisis data yang digunakan meliputi pengumpulan data (data collection), reduksi data (data reduction), penyajian data (data display), dan penarikan kesimpulan atau verifikasi (conclutions).

Hasil penelitian tindakan sekolah menemukan bahwa pada siklus I nilai rata-rata Peningkatan kompetensi guru dalam menyusun RPP yang dicapai 82,0 pada siklus II nilai rata-rata yang dicapai adalah 86,1 (80-89 = Baik) terjadi peningkatan 4,09. Hal ini berarti bahwa pelaksanaan supervisi akademik yang berkelanjutan di SD N 17 Dangin Puri dapat meningkatkan kompetensi guru dalam menyusun Rencana Pelaksanaan Pembelajaran.
\end{abstract}

Kata kunci: Kompetensi Guru, RPP, Supervisi Akademik

\section{PENDAHULUAN}

Guru mempunyai peran yang penting dalam menentukan kualitas dan kuantitas pengajaran. Oleh sebab itu, guru harus memikirkan dan membuat perencanaan secara rutin dan terprogram dalam usaha meningkatkan kualitas mengajar dan kesempatan belajar bagi siswa. Guru juga harus lebih dinamis dan kreatif dalam mengembangkan proses pembelajaran siswa (Damayanti, 2016).

Guru harus melakukan pembaruan ilmu dan pengetahuan yang dimilikinya secara terus menerus agar guru memiliki kualitas mendidik yang memadai. Kualitas 
terbaik tentunya membutuhkan strategi perencanaan pembelajaran. Perencanaan pembelajaran berfungsi untuk memberikan arah pelaksanaan pembelajaran sehingga menjadi terarah dan efisien. Salah satu bagian dari perencanaan pembelajaran yang sangat penting dibuat oleh guru sebagai pengarah pembelajaran adalah Rencana Pelaksanaan Pembelajaran (RPP).

Rencana Pelaksanaan Pembelajaran (RPP) adalah instrumen perencanaan yang dibuat untuk memandu guru dalam mengajar agar tidak melebar jauh dari tujuan pembelajaran (Supardi, 2010).

Permasalahan yang umum terjadi, RPP yang dibuat guru hanya direncanakan dalam pikiran sang guru saja, meskipun membuat, hanya sekedar meniru dan copy paste. Akibatnya kepala sekolah sebagai pembuat kebijakan di sekolah sulit mengevaluasi dengan baik kompetensi guru secara akademik yakni apakah kemampuan guru dalam mengelola pembelajaran sudah sesuai dengan harapan atau belum, atau sudahkah kompetensi dasar yang harus dikuasai oleh siswa terkuasai dengan benar.

Melihat permasalahan yang ada, kepala sekolah merencanakan untuk melakukan supervisi. Supervisi yang dilakukan adalah supervisi akademik karena berkaitan dengan penyusunan RPP yang dibuat oleh guru-guru. Esensi supervisi akademik itu sama sekali bukan menilai unjuk kerja guru dalam mengelola proses pembelajaran, melainkan membantu guru mengembangkan kompetensinya.

Majid (2005:6) menjelaskan kompetensi yang dimiliki oleh setiap guru akan menunjukkan kualitas guru dalam mengajar. Kompetensi tersebut akan terwujud dalam bentuk penguasaan pengetahuan dan profesional dalam menjalankan fungsinya sebagai guru. Dengan demikian, diyakini melalui supervisi akademik yang berkelanjutan, Guru-guru dapat meningkatkan kompetensinya dalam menyusun RPP sehingga tujuan pendidikan dan pengajaran tercapai optimal.

\section{KAJIAN PUSTAKA}

\section{Kompetensi Guru}

Muhaimin (2004:151) menjelaskan kompetensi adalah seperangkat tindakan penuh intelegen tanggung jawab yang harus dimiliki seseorang sebagai syarat untuk dianggap mampu melaksankan tugas-tugas dalam bidang pekerjaan 
tertentu. Sifat intelegen harus ditunjukan sebagai kemahiran, ketetapan, dan keberhasilan bertindak. Sifat tanggung jawab harus ditunjukkan sebagai kebenaran tindakan baik dipandang dari sudut ilmu pengetahuan, teknologi maupun etika. Diyakini Robotham (1996:27), kompetensi yang diperlukan oleh seseorang tersebut dapat diperoleh baik melalui pendidikan formal maupun pengalaman.

Pada penelitian tindakan ini, kompetensi guru dapat didefinisikan sebagai penguasaan terhadap pengetahuan, keterampilan, nilai dan sikap yang direfleksikan dalam kebiasaan berpikir dan bertindak dalam menjalankan profesi sebagai guru.

\section{Pengertian Dan Penjelasan RPP (Rencana Pelaksanaan Pembelajaran)}

Rencana pelaksanaan pembelajaran (RPP) adalah rencana yang menggambarkan prosedur dan pengorganisasian pembelajaran untuk mencapai satu kompetensi dasar yang ditetapkan dalam Standar Isi dan dijabarkan dalam silabus. Lingkup Rencana Pembelajaran paling luas mencakup satu kompetensi dasar yang terdiri atas satu indikator atau beberapa indikator untuk satu kali pertemuan atau lebih. Adapaun manfaat dari RPP (Kurniasih dan Sani, 2014:1-2) adalah:

1) Sebagai panduan dan arahan proses pembelajaran

2) Untuk memperediksi keberhasilan yang akan dicapai dalam proses pembelajaran

3) Untuk mengantisipasi berbagai kemungkinan yang akan terjadi

4) Untuk memanfaatkan berbagai sumber belajar secara optimal

5) Untuk mengorganisir kegiatan pembelajaran secara sistematis

Maka dari itu, RPP hendaknya bersifat luwes (fleksibel) dan memberi kemungkinan bagi guru untuk menyesuaikan dengan respon siswa dalam proses pembelajaran yang sesungguhnya.

\section{Supervisi}

Carter V. Good (1973) menyatakan bahwa supervisi adalah segala usaha pejabat sekolah dalam memimpin guru-guru dan tenaga kependidikan lainnya untuk memperbaiki pengajaran. Termasuk di dalamnya adalah menstimulasi, menyeleksi pertumbuhan dan perkembangan jabatan guru-guru, menyeleksi dan merevisi tujuan-tujuan pendidikan, bahkan pengajaran, dan metode-metode, serta mengevaluasi pengajaran (Mulyasa, 2011:239). 
Tujuan umum Supervisi adalah memberikan bantuan teknis dan bimbingan kepada guru dan staf agar personil tersebut mampu meningkatkan kwalitas kinerjanya, dalam melaksanakan tugas dan melaksanakan proses belajar mengajar.

Pada penelitian ini, pembahasan lebih ditekankan kepada supervisi akademik karena berkaitan dengan kompetensi guru dalam menyususn Rencana Pelaksanaan Pembelajaran.

\section{Supervisi Akademik yang berkelanjutan}

Supervisi akademik adalah serangkaian kegiatan membantu guru mengembangkan kemampuannya mengelola proses pembelajaran untuk mencapai tujuan pembelajaran (Glickman, et al, 2007). Satu hal yang perlu ditegaskan di sini, bahwa setelah melakukan penilaian kinerja bukan berarti selesailah pelaksanaan supervisi akademik, melainkan harus dilanjutkan dengan tindak lanjutnya berupa pembuatan program supervisi akademik dan melaksanakannya dengan sebaikbaiknya. Menurut Kamus Besar Bahasa Indonesia, "berkelanjutan" adalah berlangsung terus menerus, berkesinambungan.

Supervisi di atas adalah satu kerja rutinitas yang harus dilakukan oleh supervisor secara berkelanjutan karena tuntutan kurikulum yang dinamis yang terus membutuhkan penyempurnaan baik secara dokumentasi maupun secara kontekstual guna meningkatkan kompetensi guru yang nantinya akan membawa ke arah kualitas output dan sekolah, serta kualitas pendidikan secara global.

\section{Kerangka Berpikir}

Kerangka berpikir dimulai dari berlangsungnya kegiatan penelitian yang dilaksanakan oleh peneliti berawal dari input yaitu kepala sekolah selaku observer sebagai pemantau. Dalam pemantauan ini kepala sekolah melihat apa saja yang telah disiapkan yang berupa perangkat guru untuk melaksanakan tugas sebagai guru yang akan melakukan kegiatan pembelajaran. Setelah melakukan pemantauan kepala sekolah mengelompokkan apa yang menjadi temuan/permasalahan. Pada penelitian ini ditemukan kompetensi guru dalam menyusun RPP belum optimal.

Berdasarkan temuan tersebut, maka kepala sekolah dapat merencanakan proses pembimbingan atau pembinaan yakni berupaya meningkatkan kompetensi 
guru dalam menyusun Rencana Pelaksanaan Pembelajaran melalui supervisi akademik yang berkelanjutan di SD N 17 Dangin Puri. Selanjutnya kepala sekolah merumuskan hipotesis penelitian. Hipotesis ini mencoba mengemukakan jawaban sementara terhadap masalah yang akan diteliti.

Observer akan mengevaluasi proses yang telah dilaksanakan dengan melakukan pengukuran dan penilaian. Pengukuran hasil proses yang telah dilakukan seorang guru adalah dengan cara pengumpulan informasi yang hasilnya dapat dinyatakan dalam bentuk angka yang disebut skor.

Penilaian hasil proses ini adalah cara menginterpretasikan skor yang diperoleh dari pengukuran dengan mengubahnya menjadi nilai dengan prosedur tertentu dan digunakan sebagai dasar pengambilan keputusan.

Adapun kerangka berpikir dalam penelitian ini dapat ditunjukkan pada gambar 2.1.

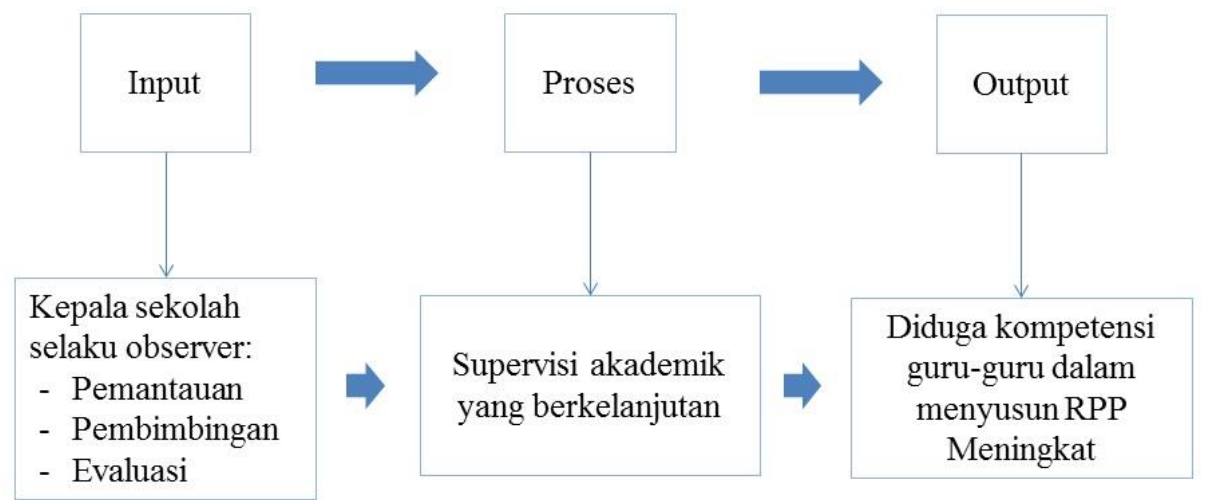

Gambar 2.1. Kerangka Berpikir

\section{Hipotesis Penelitian}

Berdasarkan kerangka berpikir tersebut di atas maka diajukan hipotesis sebagai berikut: Pelaksanaan supervisi akademik yang berkelanjutan di SD N 17 Dangin Puri dapat meningkatkan kompetensi guru dalam menyusun Rencana Pelaksanaan Pembelajaran.

\section{METODOLOGI PENELITIAN}

Lokasi penelitian ini adalah di Sekolah Dasar Negeri 17 Dangin Puri yang 
beralamat di Jalan Jl. Melati No.19 Denpasar Utara. Penelitian ini dilaksanakan pada semester I Tahun Pelajaran 2018/2019 yaitu mulai Tanggal 20 Agustus sampai dengan tanggal 17 Desember 2018.

Subyek penelitian ditentukan menggunakan tekhnik sensus yaitu tekhnik pengambilan sampel dimana subjek penelitian diambil keseluruhan untuk dijadikan sampel tanpa harus mengambil sampel dalam jumlah tertentu (Sugiyono, 2016:219). Adapun yang menjadi subyek penelitian ini adalah semua guru di SD Negeri 17 Dangin Puri yang berjumlah 12 (dua belas) guru.

Teknik pengumpulan data yang digunakan meliputi wawancara, observasi dan dokumentasi. Rancangan penelitian ini adalah model siklus yang dilakukan secara berulang dan berkelanjutan (siklus spiral) melalui dua siklus, setiap siklus meliputi tahap perencanaan, tahap tindakan dan pengamatan, serta tahap refleksi.

Kompetensi guru dalam menyusun RPP dapat diukur menggunakan indikator yang mencakup kemampuan: (1) Merencanakan pengorganisasian bahanbahan pengajaran; (2) merencanakan pengelolaan kegiatan belajar mengajar, Merencanakan pengelolaan kelas; (3) Merencanakan penggunaan media dan sumber pengajaran; dan (4) Merencanakan penilaian prestasi siswa untuk kepentingan pengajaran (Joni,1984:12).

\section{HASIL PENELITIAN DAN PEMBAHASAN}

Komponen RPP dikembangkan oleh guru pada satuan pendidikan. Guru pada satuan pendidikan berkewajiban menyusun RPP secara lengkap dan sistematis agar pembelajaran berlangsung secara interaktif, inspiratif, menyenangkan, menantang, memotivasi peserta didik untuk berpartisipasi aktif, serta memberikan ruang yang cukup bagi prakarsa, kreativitas, dan kemandirian sesuai dengan bakat, minat dan perkembangan fisik serta psikologis peserta didik.

Berdasarkan tabel dan grafik di bawah ini, dapat diketahui peningkatan kompetensi guru dalam menyusun RPP mulai dari siklus I sampai dengan siklus II. Perhatikan Tabel 4.3 di bawah ini.

\section{Tabel 4.3}


Rekap hasil penelitian Siklus I sampai dengan Siklus II

\begin{tabular}{rcccc}
\hline & Siklus I & $\begin{array}{c}\text { Siklus } \\
\text { II }\end{array}$ & $\begin{array}{c}\text { Persentase Selisih } \\
\text { (Naik/Turun) }\end{array}$ & Keterangan \\
\hline Minarsi & 83.0 & 87.0 & 4.0 & Naik \\
Desak Made Kartika & 81.0 & 87.0 & 6.0 & Naik \\
I Gusti Ayu Sri Ernawati & 80.0 & 85.0 & 5.0 & Naik \\
Pande Wishnu Ardana & 81.0 & 88.0 & 7.0 & Naik \\
Ni Kadek Sukiswari & 83.0 & 87.0 & 4.0 & Naik \\
I Made Wira Adnyana & 81.0 & 86.0 & 5.0 & Naik \\
I Nyoman Ari Wira Saputra & 81.0 & 86.0 & 5.0 & Naik \\
I Ketut Sudiadnyana & 84.0 & 86.0 & 2.0 & Naik \\
I Made Bendi & 82.0 & 84.0 & 2.0 & Naik \\
Ida Ayu Erry Yudha Virgianti & 82.0 & 84.0 & 2.0 & Naik \\
Ni Wayan Trisna Dewi & 84.0 & 87.0 & 3.0 & Naik \\
\hline Rata-rata & $\mathbf{8 2 . 0}$ & $\mathbf{8 6 . 1}$ & $\mathbf{4 . 0 9}$ & \\
\hline Sumber: Lampiran 7 & & & &
\end{tabular}

Tabel 4.3 menunjukkan nilai rata-rata pada siklus I yakni 82,0 berada pada kriteria "Baik" $(80-89)$. Hal ini bermakna penelitian tindakan sekolah pada siklus I cukup baik namun belum mencapai target penelitian dan diputuskan untuk memperbaiki beberapa langkah pada siklus II. Nilai rata-rata pada siklus II yakni 86,1 berada pada kriteria "Baik" $(80-89)$. Dengan demikian, peningkatan yang mampu dicapai selama dua siklus adalah 4,09\%.

Hasil ini sesuai dengan indikator capaian kinerja penelitian yang ditetapkan yaitu semua guru memiliki kompetensi dalam menyusun RPP minimal berada pada ketegori "Baik" dengan skor nilai rata-rata $\geq 85$.

Melihat data perolehan hasil penelitian dalam kegiatan ini, supervisi akademik yang berkelanjutan yang dilakukan oleh kepala sekolah terhadap 11 (sebelas) guru berhasil meningkatkan kompetensi mereka dalam menyusun RPP. Hal ini dimungkinkan karena adanya kerja sama yang baik antara kepala sekolah sebagai supervisor dengan para guru tersebut, yang didukung oleh adanya motivasi dan bimbingan dari kepala sekolah sehingga para guru memiliki antusiasme yang besar untuk dapat meningkatkan kemampuan mereka masing-masing dalam menyusun Rencana Pelaksanaan Pembelajaran (RPP) yang efektif dan berdaya guna sehingga tujuan pendidikan dan pengajaran tercapai optimal.

\section{SIMPULAN DAN SARAN}


Berdasarkan hasil penelitian yang telah dilaksanakan, maka dapat ditarik simpulan yakni pada siklus I nilai rata-rata Peningkatan kompetensi guru dalam menyusun RPP yang dicapai 82,0 pada siklus II nilai rata-rata yang dicapai adalah $86,1(80-89$ = Baik) terjadi peningkatan 4,09. Hal ini berarti bahwa pelaksanaan supervisi akademik yang berkelanjutan di SD N 17 Dangin Puri dapat meningkatkan kompetensi guru dalam menyusun Rencana Pelaksanaan Pembelajaran.

Sehubungan dengan simpulan diatas, maka dapat dikemukakan beberapa saran sebagai berikut:

1) Kepala sekolah diharapkan meningkatkan komitmen dengan melakukan supervisi akademik yang berkelanjutan.

2) Guru hendaknya selalu meningkatkan kompetensi, tidak bosan-bosan membaca literatur, merefleksikan diri, belajar menerima masukan dan menghargai pendapat orang lain untuk selalu siap menghadapi pendidikan modern.

3) Hasil penelitian ini dapat dijadikan sebagai acuan untuk penelitian berikutnya, dan hendaknya dilakukan penyempurnaan dalam langkahlangkah penerapannya agar diperoleh hasil yang lebih baik.

\section{DAFTAR PUSTAKA}

Carter V. Good, (ed).1973. Dictionary of Education, Third Edition. New York: McGraw-Hill.

Damayanti, Wida. 2016. Peningkatan mutu kinerja guru melalui supervisi akademik di SMK Negeri 1 Salatiga menghadapi PKG 2016 (solusi perubahan dengan gabungan model supervisi akademik artistic model dan cooperative development model). Jurnal Pendidikan Ilmu Sosial, Vol 26, No.1, Juni 2016, ISSN: 1412-3835

Daresh, J.C. 1989. Supervision as a Proactive Process. White Plains, NY: Longman.

Departemen Pendidikan Nasional. 2004. Kurikulum 2004. Jakarta : Depdiknas

Joni, Raka. 1984. Pokok-Pokok Pikiran Mengenai Pendidikan Guru. Jakarta: Direktorat Jendral Perguruan Tinggi

Kunandar. 2007. Guru Profesional: Implementasi Kurikulum Tingkat Satuan 
Pendidikan dan Sukses dalam Sertifikasi Guru. Jakarta: Raja Grafindo Persada.

Majid, Abdul. 2005. Perencanaan Pembelajaran Mengembangkan Standar Kompetensi Guru. Bandung: PT Remaja Rosdakarya

Robotham, David. 1996. Competences: Measuring The Immeasurable, Managemen Development Review, Vol. 9, No. 5, hal. 25-29

Suripto. 2016. Upaya Peningkatan Kinerja Guru Dalam Pembelajaran Melalui Supervisi Akademik Di Sekolah Dasar Dabin I UPTD Pendidikan Kecamatan Bayat Kabupaten Klaten. Magistra No. 95 Th. XXVIII Maret 2016 ISSN 0215-9511

Usman, Moh. Uzer. 1994. Menjadi Guru Profesional. Bandung: PT. Remaja Rosdakarya.

Wahjosumidjo. 2005. Kepemimpinan Kepala Sekolah, Tinjauan Teori dan Permasalahannya. Jakarta: Raja Grafindo Persada 